\title{
Interpreting Synergism Based Upon Visual-Audio-Oral Course of EAP: A Case of CI Between English and Chinese*
}

\author{
KANG Zhi-feng \\ Fudan University, Shanghai, China
}

\begin{abstract}
On the basis of the theory of relevance and transfer, this study puts forward interpreting operation synergism through positive transfer from Visual-Audio-Oral Course of EAP to E-C and C-E interpreting. In the way of consecutive interpreting, the researcher has done the experiments to 147 undergraduate interpreters of non-English majors in five classes taught by him in the second semester from 2014 to 2015. The experimental results show that listening of EAP has the functions of relevance and holistic presupposition to student interpreters, whose audio nerves have been activated once more while listening to SL (source language) information. At this moment, the function of transferring SL information as input occurs. And further, speaking of EAP also has the functions of relevance and holistic presupposition to student interpreters, whose oral nerves have been activated once more while encoding and expressing in TL (target language). At this moment the results of transferring information as TL output are prominent. Therefore, Visual-Audio-Oral Course of EAP has the effect of relevance, transfer and presupposition to student interpreters’ interpreting operation in China.
\end{abstract}

Keywords: Visual-Audio-Oral Course of EAP, relevance and transfer, consecutive interpreting (CI), synergism, teaching presupposition

\section{Introduction}

EAP (English for Academic Purposes) can be dated back to 1960s when EAP training courses, generally lasting from 4 to 12 weeks, prevailed among British and American campuses as more international students appeared. The common "learning techniques" required for EAP and other academic studies can provide language support for students’ academic studies (Dudley-Evans \& St John, 1998, p. 36). EST (English for Sciences and Technology) discourses study represented by Barber (1962) is the earliest EAP research outputs. In 1972, British Association of Lectures in EAP and EAP teaching and research gradually became the hot research fields in Applied Linguistics (YE \& YAN, 2011, p. 41). In the 1980s, Johns (1981) pointed out that the rhetoric analysis of discourses in EAP learning seemed irrelevant to the actual learning tasks, thus students' homework type and practical needs should be well known of as well. In the 1990s, Johns (1990) proposed that linked courses of English + Majors should be set up. These courses are actually linked courses of English for Specific Academic Purposes, hereinafter referred to as ESAP, which require not only English language skills, but also background

\footnotetext{
* Acknowledgements: This paper is supported by China's National Fund Program of Social Science: “A Study of China’s College Student Interpreters' Synergistic Strategy in Interpreting on the Base of ERP”. The approved No.: 15BYY011. KANG Zhi-feng, Ph.D., Professor, College of Foreign Languages and Literatures, Fudan University.
} 
knowledge of specialty. However, its application and dissemination met with some limitations. During this period, EAP teaching created a more feasible method, genre-based literacy pedagogy, since students all require similar construction and destruction (Jacoby, Leech, \& Holte, 1995). At the beginning of 21th century, Bhatia (2004) pointed out the complexity, mobility, expansibility, and unpredictability of discourses. As the College English Reform has deepened, AEAP (established in January 2015, at Fudan University) works as the incubator of EAP development and brings about much vigor and vitality. In recent years, with the continuous improvement of English levels of college students, the significance of EAP teaching has been highly recognized (CAI \& LIAO, 2010). EAP teaching and research are making progress from point to surface, from the shallower to the deeper, even from single to multi-modalities, multi-levels, multi-dimensions, multi-perspectives, and pluralism. In addition to ESAP, there are also courses of English for General Academic Purposes, hereinafter referred to as EGAP, which covers a variety of EAP courses such as listening of EAP and speaking of EAP. These courses can bring not only the effects of mapping and presupposition to interpreting subjects, but also the relevance transferring and synergizing function.

\section{Relevance and Transfer}

\section{Relevance}

Relevance refers to the connections between speaker and instant context, between utterance and listener (XIONG, 2007, p. 175). Interpreting is exactly the activity that embodies the relevance between speaker's verbal exposition and instant context, between parole and interpreter and between interpreter and audience. The Relevance Theory is founded based on exchange relevance, while interpreting is an exchange activity of decoding and encoding. And the exchange itself delivers relevance information. In this process, the relevance of conversational communication (XIONG, 2007, p. 175) can be expressed by the validity of economic proportion between the parole information processor's cognitive effort and cognitive effect of his/her spending and the contextual implication composed of physics, language and cognition.

\section{Transfer}

Transfer is a term for Cognitive Psychology of Education, and also a learning phenomenon. It refers to the positive or negative effect of the previous learning on the next (LIANG, 2009, p. 53). Scholars at home and abroad have varied opinions in regards to Transfer Theory, generally including the following four types of views: The first type is theory of formal discipline. Faculty Psychology serves as the theoretical basis. Faculties include observation, attention, memory, imagination, comprehension, judgment, impetus and willpower. Wolff C. Von. (1679-1754), a German psychologist in the 18th century, is a representative in favor of this view. The second type is theory of identical elements. The theoretical basis is the Theory of Learning Transfer which expounds from the perspective of connectionism that the original learning can only be transferred to the new learning if the original learning scenario shares the same element with the new one. Robert Sessions Woodworth (1869-1962) is one of the representatives. The third type is theory of relationship transposition. This theory emphasizes "insight", the determinant of learning transfer, and is highlighted by Gestalt psychologist Wolfgang KÖhler. The fourth type is theory of cognition transfer. This theory was proposed by an American scholar named I. M. Royer (LIANG, 2009, pp. 42-45) based on the theory that comprehension is the necessary condition for learning transfer and the possibility of transfer depends on the chance of relevant information or techniques occurring in 
the process of memory search.

It can be concluded that the function of transfer is that individuals can connect all the experiences they acquired together in complex ways and then apply them to solve a certain kind of problem. The new acquired experience can sometimes change the original experience structure. Different experiences can form new experience structure after recombination. The interaction between experiences in such a way can be regarded as learning transfer. Through transfer, both the new and old experience can be generalized and systematized so as to form an integrated psychological structure and adjust individual behavior steadily. In addition to insight, comprehension is also of vital importance in this process, for which the synergizing function of positive transfer can be realized.

\section{Hypotheses}

The Relevance Theory proposed by XIONG (2007, p. 175) defined the relevance between speaker and instant context, and between utterance and listener. So we can infer that the Visual-Audio-Oral Course of EAP has relevance to E-C and C-E interpreting with high instant context. Moreover, the Visual-Audio-Oral Course of EAP and that of E-C and C-E interpreting are also relevant to each other. LIANG (2009, p. 53) put forward that the Transfer Theory indicates the positive or negative effect of the previous learning on the latter. Thus, he raised a question of whether the Visual-Audio-Oral Course of EAP as the previous learning has a transfer effect on the E-C and C-E interpreting. If so, is it positive or negative?

To figure it out, we might as well make two hypotheses: (1) The Visual-Audio-Oral Course of EAP does have relevance to E-C and C-E interpreting; (2) EAP has the synergism effect to the E-C and C-E interpreting.

Empirical studies are still required to further prove whether there are relevance and synergism effects between the Visual-Audio-Oral Course of EAP and the E-C and C-E interpreting and whether the ICM (Idealized Cognitive Models) can be realized through cognition of them both.

\section{Synergism Effect of Audio-EAP to Identification and Comprehension in CI}

\section{Auditory Process Model}

Auditory Process Model can be divided into two categories. One is a bottom-up processing depending on the stimuli features or the sensory information from the external input. The other is a top-down processing based on the existing knowledge structure. The importance of these two ways of processing varies with the task type and the cognitive activity (PENG \& ZHANG, 2004, p. 6). While Richards (2006) came up with another three models of auditory processing: a Bottom-up Processing Model, a Top-down Processing Model, and an Interactive Processing Model. Functioning as the processing of auditory cognitive information, these three models are all applicable to the auditory cognitive processing in both listening of EAP and E-C and C-E interpreting. This processing of auditory information generates similarity gain and otherness synergism to the auditory cognition in listening of EAP and E-C and C-E interpreting.

\section{Similarity Synergism}

Listening of EAP share natural similarities with E-C consecutive interpreting (hereinafter referring to $\mathrm{CI}$ ) in aspects of preparation before listening, auditory cognition, subjects of listening, contents, and teaching methodology: (1) Preparation before listening: psychological preparation of attention and material preparation of 
papers and pens; (2) Auditory cognition: requirement of information identification and information option to the auditory perception of input information; (3) Subjects of listening: various types of literature, such as English discourses of lectures, news, and interviews from BBC, CNN, and TED, as shown in Table 1; (4) Teaching methodology: application of teaching methodologies of modern all-encompassing with multimodalities (KANG, 2012b, p. 34), especially frequently utilized in Visual-Audio-Oral Course of EAP and E-C and C-E interpreting classrooms. In this regard, the similarities have an effect of synergism to the listening of CI.

\section{Otherness Synergism}

On the other hand, listening of EAP also has some artificial and disciplinary otherness with CI in the areas of preparation before listening, auditory cognition, and process after listening: (1) Preparation before listening. CI requires more attention in psychological preparation than listening of EAP, which tends to cause high anxiety to student interpreters (KANG, 2012a, p. 42). In the meantime, materials of papers and pens are prepared for students to write down important information at any time in listening of EAP, while sufficient pieces of note-taking papers and note-taking pens are demanded in CI material preparation. (2) Auditory cognition. Students are taught to listen to, select, and write down key points after auditory perception of source language (hereinafter referring to SL) in listening of EAP (KANG, 2011a, p. 81). However, in CI classrooms, students are asked to take coherent notes while listening as well as to actively identify, comprehend, and select information with ears, eyes, and hearts. (3) Process after listening. As for actions after listening, in listening of EAP, multiple-choices or question-answering are given to students to tell whether they have comprehended the English discourses. But in CI classrooms, students are demanded to interpret the discourse in Chinese as shown in Table 1. In all, from the theoretical perspective, the listening of CI based on listening of EAP has the effect of synergism, but the authenticity of this conclusion still needs to be verified through empirical studies.

Table 1

Similarities and Otherness Between Listening of EAP and Listening of CI

\begin{tabular}{|c|c|c|c|c|}
\hline Features & Stages and Subjects & Contents & Listening of EAP & Listening of CI \\
\hline \multirow{4}{*}{ Similarity } & \multirow{2}{*}{$\begin{array}{l}\text { Preparation before } \\
\text { listening }\end{array}$} & $\begin{array}{l}\text { Psychological } \\
\text { preparation }\end{array}$ & Attention & Attention \\
\hline & & Material preparation & \multirow{3}{*}{$\begin{array}{l}\text { Papers and pens } \\
\text { Information identification, } \\
\text { information option } \\
\text { Discourses with types of } \\
\text { literature like lectures, press } \\
\text { and interviews and themes like } \\
\text { economy and diplomacy }\end{array}$} & Papers and pens \\
\hline & Auditory cognition & Auditory perception & & $\begin{array}{l}\text { Information identification, information } \\
\text { option }\end{array}$ \\
\hline & Subjects of listening & English discourses & & $\begin{array}{l}\text { Discourses with types of literature like } \\
\text { lectures, press and interviews and } \\
\text { themes like economy and diplomacy }\end{array}$ \\
\hline \multirow{4}{*}{ Otherness } & \multirow{2}{*}{$\begin{array}{l}\text { Preparation before } \\
\text { listening }\end{array}$} & $\begin{array}{l}\text { Psychological } \\
\text { preparation }\end{array}$ & Attention & More attention \\
\hline & & Material preparation & Papers and pens & Note-taking papers (note-taking pens) \\
\hline & Auditory cognition & Auditory perception & $\begin{array}{l}\text { Identification and } \\
\text { comprehension, mainly for } \\
\text { listening, taking notes for the } \\
\text { key points }\end{array}$ & $\begin{array}{l}\text { Active identification and comprehension } \\
\text { with student interpreters' ears, eyes and } \\
\text { hearts, taking notes consecutively while } \\
\text { listening }\end{array}$ \\
\hline & Process after listening & Actions after listening & $\begin{array}{l}\text { Multiple choices or } \\
\text { question-answering }\end{array}$ & Expressing in Chinese \\
\hline
\end{tabular}

\section{Empirical Studies}

The researcher conducted an investigation and survey to 147 undergraduate interpreters of non-English 
majors in 5 classes taught by him in the second semester from 2014 to 2015. This research aims to figure out whether listening of EAP Course is beneficial to the listening of CI after collecting data from those undergraduate interpreters who had taken the Listening of EAP Course before and to what degree it is efficient.

Survey 1: Approved number of students. The Table 2 below shows the approved number of students having taken the Interpreting Course between English and Chinese (hereinafter referred to as ICEC) and Listening of EAP Course (hereinafter referred to as L/EAP Course).

Table 2

A Survey of Students Having Taken Listening of EAP Course and Interpreting Course

\begin{tabular}{|c|c|c|c|c|c|c|}
\hline Class & S/ICEC & $\begin{array}{l}\text { Percentage of } \\
\text { T/ICEC }\end{array}$ & S/L/EAP & $\begin{array}{l}\text { Percentage of } \\
\text { T'/ICEC }\end{array}$ & $\begin{array}{l}\text { Proportion of } \\
\text { T/ICEC }\end{array}$ & Time, location and level \\
\hline ENGL110043.08 & 30 & 20.408 & 6 & 20.000 & 4.082 & $\begin{array}{l}\text { W3-4/HGX401/ } \\
\text { Fulfilled College English III }\end{array}$ \\
\hline ENGL110043.09 & 30 & 20.408 & 10 & 33.333 & 6.803 & $\begin{array}{l}\text { W6-7/HGX401/ } \\
\text { Fulfilled College English III }\end{array}$ \\
\hline ENGL110043.10 & 29 & 19.728 & 11 & 37.931 & 7.483 & $\begin{array}{l}\text { T3-4/HGX401/ } \\
\text { Fulfilled College English III }\end{array}$ \\
\hline ENGL110043.11 & 29 & 19.728 & 9 & 31.035 & 6.122 & $\begin{array}{l}\text { T6-7/HGX401/ } \\
\text { Fulfilled College English III }\end{array}$ \\
\hline ENGL110043.12 & 29 & 19.728 & 9 & 31.035 & 6.122 & $\begin{array}{l}\text { T8-9/HGX401/ } \\
\text { Fulfilled College English III }\end{array}$ \\
\hline Total & 147 & 100 & 45 & - & 30.612 & - \\
\hline
\end{tabular}

(S/EI = Students who had taken ICEC Course; T/ICEC = Total number of students who took ICEC Course; S/L/EAP = Students who had taken L/EAP Course; T'/ICEC = Total number of student who took ICEC Course in the class).

It can be inferred from Table 2 that among all of the 147 undergraduate interpreters who took ICEC Course, 45 of them had studied L/EAP Course, reaching $30.612 \%$ of all.

Survey 2: Mark comparison. The researcher selected 12 paragraphs of A Time for Celebration (Speech at the Reception to Celebrate the 60th Anniversary of the PRC) (KANG, 2013, pp. 42-43) as the test material. One hundred and forty-seven undergraduate interpreters in 5 classes were given the listening test of E-C consecutive interpreting. In the form of dictation, students were required to write down what they had heard. The full mark is 100. Results are shown below in Table 3.

Table 3

Results of Listening Test of E-C Consecutive Interpreting

\begin{tabular}{|c|c|c|c|c|c|}
\hline Item & Num & & Percentage of T/ICEC & Average mark I of LT/I & Average mark II of LT/I \\
\hline \multirow{2}{*}{ S/L/EAP } & \multirow{2}{*}{45} & S/M (A/A-): 38 & 25.850 & 87.142 & \multirow{2}{*}{-81.891} \\
\hline & & $\mathrm{S} / \mathrm{M}(\mathrm{B}+/ \mathrm{B} / \mathrm{B}-): 7$ & 4.762 & 76.639 & \\
\hline S/Non-L/EAP & 102 & & 69.388 & 73.801 & 73.801 \\
\hline Total & 147 & & 100 & 79.194 & 77.846 \\
\hline
\end{tabular}

(T/ICEC = Total number of students who took ICEC Course; LT/I = Listening test of interpreting; S/L/EAP = Students who had taken L/EAP Course; S/M (A/A-) = Students with mark of A and A- in L/EAP Course; S/M (B+/B/B-) = Students with mark of B+, $\mathrm{B}$ and $\mathrm{B}-$ in L/EAP Course; S/Non-L/EAP = Students who had not taken L/EAP Course).

It can be obtained from Table 3 that these 45 undergraduate interpreters who had taken L/EAP Course got an average mark of 81.891. Therein, 38 of them who achieved excellence in L/EAP Course in particular performed better in the test with an average mark of 87.142, largely higher than the average of 79.194 among those who had 
not taken the L/EAP Course (shown in Figure 1).

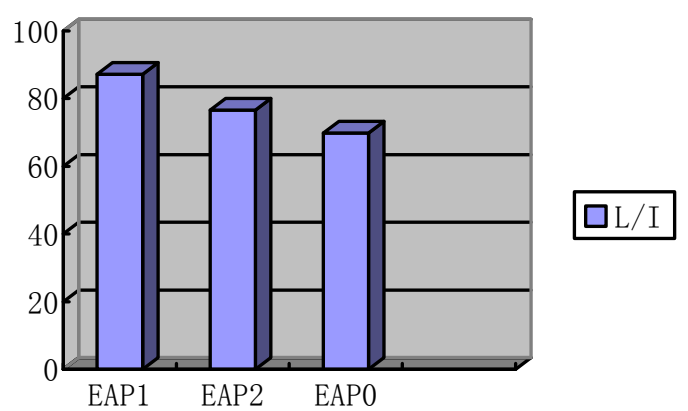

Figure 1. Diagram of listening test mark.

(EAP1 = Students who achieved excellence in the L/EAP Course; EAP2 = Students who performed good in the L/EAP Course; EAP0 $=$ Students who had not taken the L/EAP Course; L/I = Listening in the Interpreting Course).

It can thus be proved that the L/EAP has the effect of similarity and otherness synergism to the L/CI with an average mark effect of 8.090 and that of 13.341 to those who achieved excellence in the L/EAP Course. L/EAP has the functions of holistic presupposition and teaching presupposition effect and L/CI has the effect of synergism. In such a way, the ICM of L/EAP to L/CI can be realized.

\section{Synergism Effect of Oral-EAP to C-E Interpreting Output}

\section{Curriculum Construction of Oral-EAP Course}

Oral-EAP Course (hereinafter referred to as O/EAP Course) includes courses of Practical Communicative Oral English, English Public Speech and so on. These oral courses are constructed to create a casual context for students to discuss freely in Standard English. This is helpful to train their coordination abilities and let them express their own insights so as to teach them the skills of making academic and commercial reports. At the same time, students can improve their abilities of negotiating and consulting with international companies with ease in Standard English. Students can select any topic for their speech or debate, such as business, environment, culture, etc. to make their own contribution for the development of company. They can either make analysis of the advantages and disadvantages of products or make prospect forecast, or address advice for urban planning and development, or provide measurements for the environmental management or point out a direction for cultural development and exchange. The Oral-EAP test can be carried out in the form of speech, answering questions, or group discussions. This construction of Oral-EAP Course is conducive to strengthening students' oral competence and exerting a synergism effect on the C-E interpreting of student interpreters in English Interpreting classrooms.

\section{Synergism Research}

The researcher conducted a questionnaire to 147 undergraduate interpreters of non-English majors in 5 classes taught by him in the second semester from 2014 to 2015. This research aims to find out whether the Oral-EAP Course has a synergism effect on the students' interpreting level after collecting the data from students having taken the O/EAP Course before and to what degree it is efficient.

Step 1: Approved Number of Students. 
The number of students who had taken the O/EAP Course is shown below in Table 4.

Table 4

Number of Students Having Taken the O/EAP Course

\begin{tabular}{lllll}
\hline Classes & S/ICEC & S/O/EAP & Percentage of T'/ICEC & Percentage of T/ICEC \\
\hline ENGL110043.08 & 30 & 7 & 23.333 & 4.762 \\
ENGL110043.09 & 30 & 9 & 30.000 & 6.122 \\
ENGL110043.10 & 29 & 12 & 41.379 & 8.163 \\
ENGL110043.11 & 29 & 10 & 34.483 & 6.803 \\
ENGL110043.12 & 29 & 10 & 34.483 & 6.803 \\
Total & 147 & 48 & - & 32.653 \\
\hline
\end{tabular}

(S/ICEC = Students who had taken ICEC Course; S/O/EAP = Students who had taken the O/EAP Course; T’/ICEC = Students who had taken the ICEC Course in this class; T/ICEC = Total number of students who had taken the ICEC Course).

It can be shown from Table 4 that 48 out of 147 student interpreters had taken O/EAP Course, accounting for $32.653 \%$ of the total number.

Step 2: Mark Comparison.

The C-E interpreting transcript Part B: Passage 1 and Passage 2 in the simulation test 2 of An Advanced Course of Interpretation (KANG, 2011b, p. 238) were selected as the testing material. One hundred and forty-seven student interpreters in 5 classes took this test of target language (hereinafter referred to TL) expression and their consecutive interpreting from Chinese to English were recorded to be graded. The full mark is 100 and the results are shown in Table 5 below.

Table 5

Testing Results of TL Expression in C-E Consecutive Interpreting

\begin{tabular}{|c|c|c|c|c|c|}
\hline Item & Num & er of students & Percentage of T/ICEC & $\begin{array}{l}\text { Interpreting output } \\
\text { Average Mark I of } \\
\text { interpreting output \&TL } \\
\text { expression test }\end{array}$ & $\begin{array}{l}\text { Interpreting output } \\
\text { Average Mark II of } \\
\text { interpreting output \& TL } \\
\text { expression test }\end{array}$ \\
\hline \multirow{2}{*}{$\begin{array}{l}\text { Students who had } \\
\text { taken Oral-EAP } \\
\text { Course }\end{array}$} & \multirow[t]{2}{*}{48} & $\begin{array}{l}\text { S/M' } \\
\text { (A/A-): } 41\end{array}$ & 27.891 & 86.411 & \multirow[t]{2}{*}{82.369} \\
\hline & & S/M' (B+/B/B-): 7 & 4.762 & 78.326 & \\
\hline S/Non-O/EAP & 99 & & 67.347 & 71.047 & 71.047 \\
\hline Total & 147 & & 100 & 78.595 & 76.708 \\
\hline
\end{tabular}

(T/ICEC $=$ Total number of students who had taken the ICEC Course; S/M' (A/A-) = Students with mark of A and A- in O/EAP Course; S/M' $(\mathrm{B}+/ \mathrm{B} / \mathrm{B}-)=$ Students with mark of B+, B and B- in O/EAP Course; S/Non-O/EAP = Students who had not taken O/EAP Course).

It can be concluded from Table 5 that these 48 undergraduate interpreters who had taken O/EAP Course obtained an average score of 82.369. Particularly, 41 students with scores of A or A-in O/EAP Course performed much better than those with average in the C-E consecutive interpreting output, with an average score of 86.411. This figure is 8.085 higher than that for students with scores of $\mathrm{B}+$ and $\mathrm{B}$, and largely exceeds the average mark (71.047) of students who had not taken O/EAP Course. The gap between 82.369 (obtained by those with A and A- in learning O/EAP) and 71.047 (obtained by those who had not taken O/EAP) is 15.364 (as seen in Figure 2). 


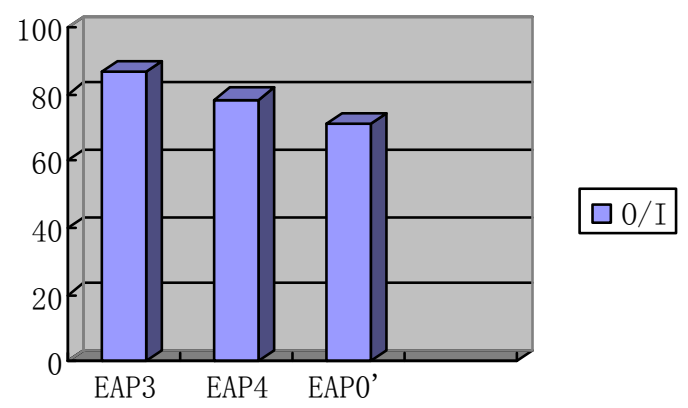

Figure 2. Diagram of students' scores in TL expression test of C-E consecutive interpreting.

(EAP3 = Students with excellent mark in Oral-EAP Course; EAP4 = Students with good score in Oral-EAP Course; EAP0' = Students who had not taken Oral-EAP Course; O/I = Interpreting output).

It can thus be seen from Figure 2 that in the histogram EAP3 has higher score than EAP4 and evidently better than EAP0', 15.364 scores higher. This proves that Oral-EAP Course has a holistic synergism effect on the TL expression of C-E consecutive interpreting.

\section{Discussion}

\section{Relevance, Reliability, and Validity}

To further verify the relevance, authenticity, reliability, and validity of this experiment, the research calculated the relevance of L/EAP and L/I with SPSS.20 software. The data were automatically generated as shown below in Table 6 .

Table 6

Relevance of $L / E A P$ and $L / I$

\begin{tabular}{lllll}
\hline & & VAR00001 & VAR00002 & VAR00003 \\
\hline \multirow{2}{*}{ VAR00001 } & Pearson Relevance & 1 & $1.000^{* *}$ & $-1.000^{* *}$ \\
& Significance (two-tailed) & & $\cdot$ & $\cdot$ \\
\hline \multirow{3}{*}{ VAR00002 } & $\mathrm{N}$ & 2 & 2 & 2 \\
& Pearson Relevance & $1.000^{* *}$ & 1 & $-1.000^{* *}$ \\
& Significance (two-tailed) & $\cdot$ & 2 & $\cdot$ \\
\hline \multirow{2}{*}{ VAR00003 } & $\mathrm{N}$ & 2 & $-1.000^{* *}$ & 2 \\
& Pearson Relevance & $-1.000^{* *}$ & $\cdot$ & 2 \\
\hline
\end{tabular}

**Significantly relevant at the .01 level (two-tailed).

(VAR00001 $=$ Number of L/EAP vs. that of non L/EAP; VAR00002 $=$ Percentage of L/EAP vs. that of non L/EAP; VAR00003 = Mark of L/EAP vs. that of non L/EAP).

It may be inferred from the results that there is two-tailed significant relevance between L/EAP and non L/EAP, between percentage of L/EAP and that of non L/EAP, and between Mark of L/EAP and that of non L/EAP. Therefore, there is significant relevance between L/EAP and L/I at the level of .01 (two-tailed).

From Table 7 Single Sample Test, it can be found that the Sig. (two-tailed) of these three items are .235, .236, and .033, meaning that all experiments are statistical significant. Through SPSS reliability calculation, the result 
shows that the Cronbach's Alpha of these 3 testing items is .560, a relatively high reliability, as shown in Table 8 .

The results of SPSS validity calculation are shown in the following Tables 9-1/2/3 (Due to software limitations, only double digits behind decimal points are reserved):

Table 7

Single Sample Test

\begin{tabular}{lllllll}
\hline & \multirow{2}{*}{$\mathrm{t}$} & $\mathrm{df}$ & \multirow{2}{*}{ Sig.(two-tailed) } & \multirow{2}{*}{ Difference of mean value } & \multicolumn{2}{c}{ Confidence interval 95\% of difference } \\
\cline { 6 - 7 } & & & & & Lower limit & Upper limit \\
\hline VAR00001 & 2.579 & 1 & .235 & 73.50000 & -288.6268 & 435.6268 \\
VAR00002 & 2.579 & 1 & .236 & 50.00000 & -196.3733 & 296.3733 \\
VAR00003 & 19.245 & 1 & .033 & 77.84600 & 26.4494 & 129.2426 \\
\hline
\end{tabular}

Table 8

Reliability Statistics

\begin{tabular}{ll}
\hline Cronbach's Alpha & Item \\
\hline .560 & 3 \\
\hline
\end{tabular}

Table 9-1

Validity Check of the Number of L/EAP and Non L/EAP

\begin{tabular}{llllll}
\hline & & Frequency & Percentage & Valid percentage & Cumulative percentage \\
\hline \multirow{4}{*}{ Valid } & 45.00 & 1 & 50.0 & 50.0 & 50.0 \\
& 102.00 & 1 & 50.0 & 50.0 & 100.0 \\
& Total & 2 & 100.0 & 100.0 & \\
\hline
\end{tabular}

Table 9-2

Validity Check of the Percentage of L/EAP and Non L/EAP

\begin{tabular}{llllll}
\hline & & Frequency & Percentage & Valid percentage & Cumulative percentage \\
\hline \multirow{4}{*}{ Valid } & 30.61 & 1 & 50.0 & 50.0 & 50.0 \\
& 69.39 & 1 & 50.0 & 50.0 & 100.0 \\
& Total & 2 & 100.0 & 100.0 & \\
\hline
\end{tabular}

Table 9-3

Validity Check of Mark of L/EAP and Non L/EAP

\begin{tabular}{llllll}
\hline & & Frequency & Percentage & Valid percentage & Cumulative percentage \\
\hline \multirow{3}{*}{ Valid } & 73.80 & 1 & 50.0 & 50.0 & 50.0 \\
& 81.89 & 1 & 50.0 & 50.0 & 100.0 \\
& Total & 2 & 100.0 & 100.0 & \\
\hline
\end{tabular}

Thus, it can be seen that the testing items are all $100 \%$ valid.

Similarly, by calculating the relevance between O/EAP and O/I, it also turns out that both are significantly relevant at the level of .01 (two-tailed), with the reliability value of .433, testing items of 3, Sig. (two-tailed) values of .213, .213 and .047, and validity value of $100 \%$. This proves the relevance between O/EAP and O/I and the reliability and validity of the experiment.

Hence, two hypotheses can be proved:

(1) There is relevance between EAP and English Interpreting; 
(2) It is true that there is transfer and synergism effect of EAP on English Interpreting. This cognition can realize ICM and play the function of holistic presupposition and pedagogical presupposition.

\section{Common Core Correlation Between EAP and Interpreting}

The experiments above have verified the synergism of EAP to Consecutive Interpreting. The reasons behind it are the three common core dimensions between them: language skill dimension, cogitating dimension, and meta cognition dimension. As for language skill dimension, from the basic word + sentence + discourse skill to synergized word + synergized sentence + synergized discourse skill; in regards of cogitating dimension, from critical thinking ability in the Age of Big Data to synergized creative thinking ability; for meta cognition dimension, from self-study management ability to synergized meta cognition ability.

Table 10

The Common Core Dimensions Between EAP and Interpreting

\begin{tabular}{|c|c|c|c|c|c|}
\hline Factor/ & Dimension/Item & EAP & Degree & CI & Degree \\
\hline \multirow{3}{*}{$\begin{array}{l}\text { Three } \\
\text { connotations }\end{array}$} & $\begin{array}{l}\text { Language skill } \\
\text { dimension }\end{array}$ & Word + sentence + discourse & Basis & $\begin{array}{l}\text { Synergized word + synergized sentence } \\
+ \text { synergized discourse }\end{array}$ & Synergizing \\
\hline & Cogitating dimension & $\begin{array}{l}\text { Critical thinking ability in the } \\
\text { age of big data }\end{array}$ & Basis & Synergized language thinking ability & Synergizing \\
\hline & $\begin{array}{l}\text { Meta cognition } \\
\text { dimension }\end{array}$ & $\begin{array}{l}\text { Self-study management } \\
\text { ability }\end{array}$ & Basis & Synergized meta cognition ability & Synergizing \\
\hline
\end{tabular}

From the table above, it can be illustrated that EAP is the basis of three connotation dimensions and the three-dimension synergized interpreting is the result. The construction is shown in Figure 3.

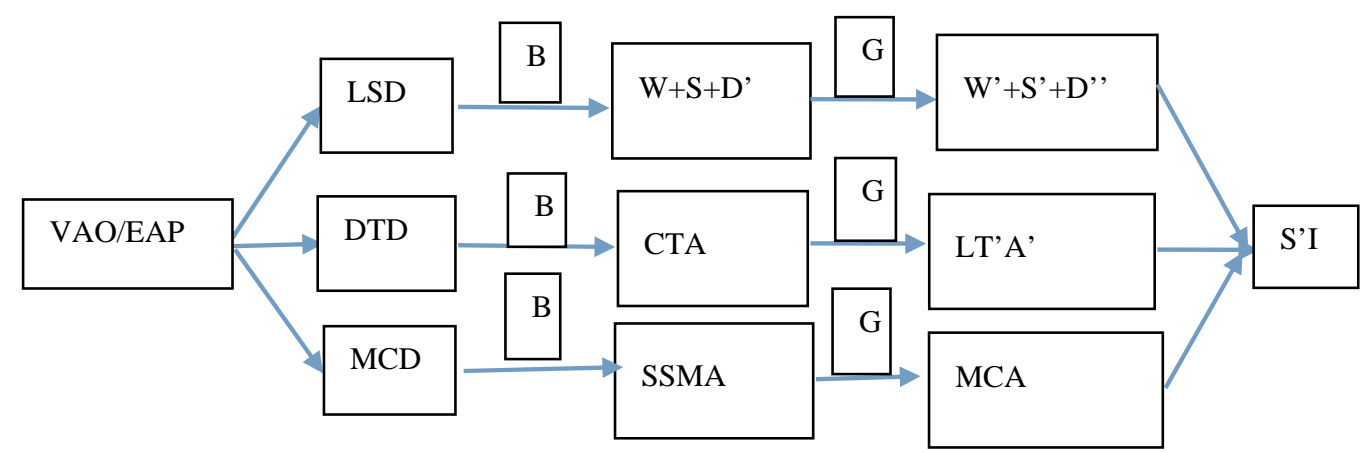

Figure 3. Construction of EAP connotation dimension to interpreting synergism.

(VAO/EAP = visual-audio-oral course of EAP; LTD = language technology dimension; DTD = deep thinking dimension; MCD = meta cognition dimension; $\mathrm{B}$ = basis; $\mathrm{W}+\mathrm{S}+\mathrm{D}^{\prime}$ = word + sentence + discourse; CTA = critical thinking ability; SSMA = self-study management ability; $\mathrm{G}=$ synergism; $\mathrm{W}^{\prime}+\mathrm{S}^{\prime}+\mathrm{D}^{\prime}$ ' = synergized word + synergized sentence + synergized discourse; LT'A' = synergized language thinking ability; MCA = synergized meta cognition ability; S'I = synergized interpreting.)

\section{Limitations}

(1) The research has a relatively high validity of input experiment (listening) while there are still differences in undergraduate interpreters' SL understanding, TL coding, and personal emotions in the output experiment (interpreting);

(2) There is a slight deficiency in the research of Visual part, which needs to be further studied;

(3) This research only covers the synergism research of visual-audio-oral course of EAP to English Interpreting. The others are all considered as research topics to be studied. 


\section{Prospects}

The synergism effect of other courses of EAP to English interpreting should be further investigated (as shown in Figure 4), which embraces broad prospects.

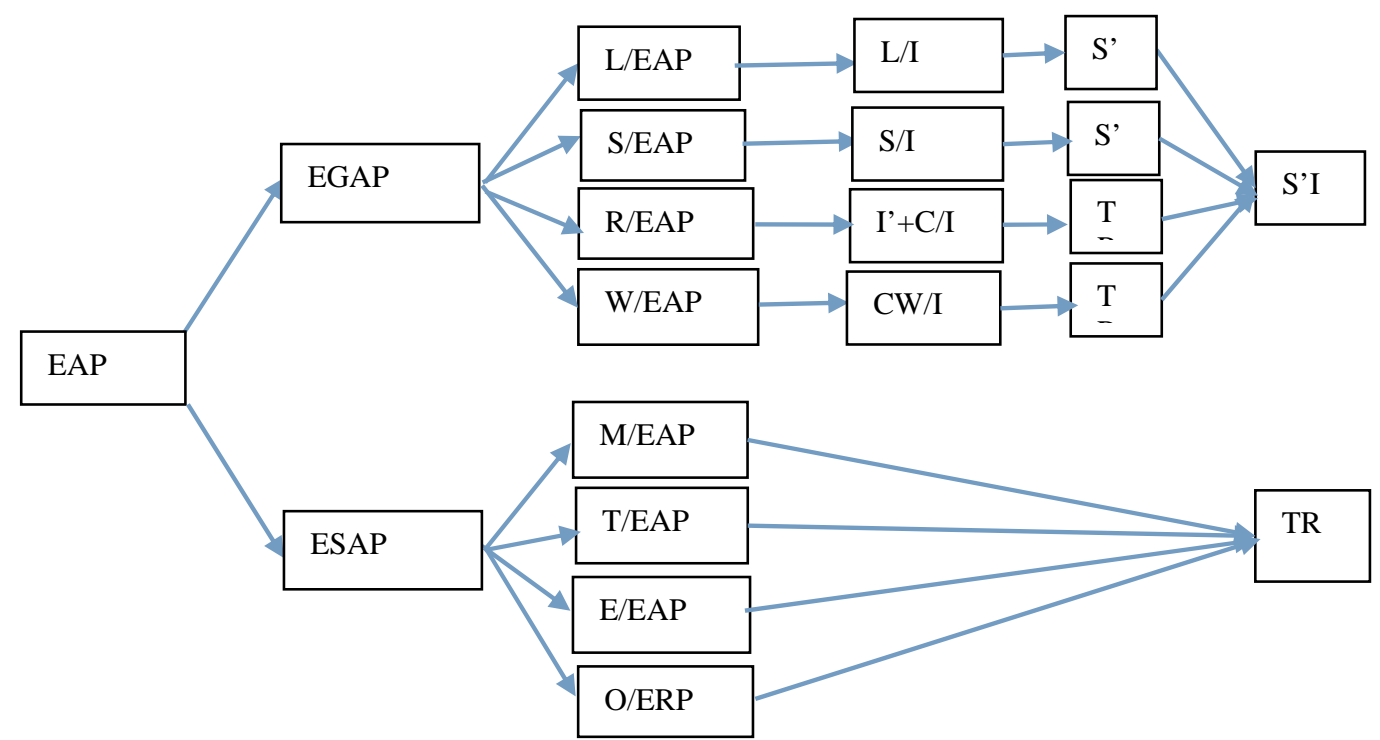

Figure 4. Spanning graph of EAP synergism to interpreting.

$(\mathrm{L}$ = listening; $\mathrm{R}$ = reading; $\mathrm{S}$ = speaking; $\mathrm{W}$ = writing; $\mathrm{I}=$ interpreting; $\mathrm{I}$ ' = identification; $\mathrm{C}=$ comprehension; $\mathrm{CW}=$ creative writing; $\mathrm{S}^{\prime}=$ synergism; $\mathrm{S}$ 'I = synergism interpreting; $\mathrm{M}=$ medicine; $\mathrm{T}$ = technology; $\mathrm{E}=$ engineer; $\mathrm{O}=$ ocean; $\mathrm{TR}=$ to be researched.)

\section{Conclusion}

From the experiments on the synergism effect of EAP to consecutive interpreting, it can be concluded that L/EAP has relevance and holistic presupposition function to L/I of undergraduate interpreters whose auditory nerves have been activated once more while encoding and expressing in TL although more research is still needed to further study in SL understanding, TL encoding, personal emotions, and EAP writings. O-EAP has relevance and holistic function to undergraduate interpreters whose oral nerves have been activated once more while encoding and expressing in TL. Therefore, EAP has relevance, transfer, and pedagogical presupposition functions to interpreting output of undergraduate interpreters. This effect of warming up, incubation, and enforcement promotes the teaching of interpreting between English and Chinese.

\section{References}

Barber, C. L. (1962). Some measurable characteristics of modern scientific prose. In J. Swales (Ed.), Episodes in ESP. Hemel Hempstead: Prentice-Hall, International.

CAI, J. G., \& LIAO, L. C. (2010). EAP vs. ESP—The orientation of college English. Foreign Language Education, 6, 47-50.

Dudley-Evans, T., \& St John, M. J. (1998). Developments in ESP: A multi-disciplinary approach. Cambridge: Cambridge University Press.

Jacoby, S., Leech, D., \& Holte, C. (1995). A genre based developmental writing course for undergraduate ESL science majors. In D. Belcher and G. Braine (Eds.), Academic writing in a second language: Essays on research and pedagogy (pp. 351-373). Norwood, NJ: Ablex.

Johns, A. M. (1981). Necessary English: A faculty survey. TESOL Quarterly, 15(1), 51-57.

Johns, A. M. (1990). Coherence as a cultural phenomenon: Employing ethnographic principles in the academic milieu. In U. Connor and A. M. Johns (Eds.), Coherence in writing: Research and pedagogical perspective (pp. 209-226). Alexandria, AV: TESOL. 
KANG, Z. F. (2011a). Consecutive interpreting and “AA+EA” strategy. Foreign Language Learning Theory and Practice, $2,81$.

KANG, Z. F. (2011b). An advanced course of interpretation. Shanghai: East China University of Science and Technology Press.

KANG, Z. F. (2012a). A study of auditory anxiety with multimodalities in interpreting assisted by modern technology [J]. Computer Assisted Foreign Language Education (3), 42.

KANG, Z. F. (2012b). The all-encompassing theory and interpreting teaching with multimodalities. Foreign Language World, 5 , 34.

KANG, Z. F. (2013). A course book of interpreting practice in E-C and C-E. Beijing: National Defense Industry Press.

LIANG, N. J. (2009). Applied cognitive psychology. Shanghai: Shanghai Education Press.

PENG, R. L., \& ZHANG, B. Y. (2004). Cognitive psychology. Hangzhou: Zhejiang Education Press.

Richards, J. (2006). Second language listening: Theory and practice. Cambridge: Cambridge University Press.

XIONG, X. L. (2007). New perspectives of linguistics. Shanghai: Fudan University Press.

YE, Y. P., \& YAN, P. F. (2011). Exploration of a writing-through-reading teaching approach for EGAP courses. Foreign Language World, 5, 41.

\section{Appendix: About the Author}

Professor of Interpreting Studies in College of Foreign Languages and Literatures at Fudan University, Secretary General of China English for Academic Purposes Association (CEAPA), Standing Director of China Rhetoric Association (SCRA), Standing Director of China Association of Language \& Education (CALE), Expert Member of Translators Association of China (TAC), Expert Member of China Theory and Teaching of Applied Translation Council (CTTATC), Blind Reviewer of Journal of PLA University of Foreign Languages, Member of China Association for Comparative Studies of English and Chinese (CACSEC), Member of Translation Studies Affiliated to China Comparative Literature Association. 